\title{
PENGARUH PENAMBAHAN BERBAGAI JENIS SERAT PADA KUAT TEKAN PAVING BLOCK
}

\author{
Fauna Adibroto ${ }^{1}$
}

\begin{abstract}
ABSTRAK
Umumnya paving block digunakan untuk perkerasan jalan, pedestrian dan trotoar. Selain itu dapat juga digunakan pada area khusus seperti area pelabuhan peti kemas, lahan parkir, area terbuka dan area industri. Penggunaan paving block sangatlah mendukung go green yang telah dikumandangkan secara nasional/internasional, karena daya serap air melalui pemasangan paving block dapat menjaga keseimbangan air tanah. Penelitian laboratorium ini menguji kuat tekan paving block dengan penambahan serat (ijuk, plastik dan kawat) pada benda uji dengan kadar dari $1 \%$ sampai 5\% dari volume campuran paving block.. Dari penelitian ini diharapakan memperoleh paving block dengan mutu kuat tekan yang tinggi. Dan berdasarkan hasil pengujian yang diperoleh ternyata secara prinsip ternyata penambahan serat (ijuk, plastik, kawat) sampai $5 \%$ terhadap campuran paving block tidak memberikan nilai yang significant terhadap penambahan kuat tekan paving block, malah sebagian campuran memberikan kecenderungan penurunan kuat tekan dibandingkan dengan kuat tekan paving block standar sebagai pembanding. Untuk penambahan serat ijuk kekuatan tekan rata-rata maksimum hanya diperoleh sebesar $323,98 \mathrm{~kg} / \mathrm{cm} 2$ pada penambahan serat ijuk panjang $3 \mathrm{~cm}$ dengan persentase penambahan serat $2 \%$. Untuk penambahan serat plastik kekuatan tekan ratarata maksimum hanya diperoleh sebesar $325,10 \mathrm{~kg} / \mathrm{cm} 2$ pada penambahan serat ijuk panjang $2 \mathrm{~cm}$ dengan persentase penambahan serat $3 \%$. Sedangkan untuk penambahan serat kawat kekuatan tekan rata-rata maksimum hanya diperoleh sebesar $341,52 \mathrm{~kg} / \mathrm{cm} 2$ pada penambahan serat ijuk panjang $3 \mathrm{~cm}$ dengan persentase penambahan serat $3 \%$.
\end{abstract}

Kata kunci : paving block, serat (ijuk, kawat, plastik), kuat tekan

\section{PENDAhuluan}

Paving block banyak digunakan dalam bidang konstruksi dan merupakan salah satu alternatif pilihan untuk lapis perkerasan permukaan tanah. Kemudahan dalam pemasangan, perawatan yang relatif murah serta memenuhi aspek keindahan mengakibatkan paving block lebih banyak disukai. Umumnya paving block digunakan untuk perkerasan jalan, pedestrian dan trotoar. Selain itu dapat juga digunakan pada area khusus seperti area pelabuhan peti kemas, lahan parkir, area terbuka dan area industri. Penggunaan paving block sangatlah mendukung go green yang telah dikumandangkan secara nasional/internasional, karena daya serap air melalui pemasangan paving block dapat menjaga keseimbangan air tanah.

Penggunaan pada area tertentu (khusus) menuntut penggunaan paving block dengan mutu lebih baik dari pada penggunaan pada pedestrian atau trotoar. Untuk dapat berfungsi dengan baik, dibutuhkan paving block yang mempunyai nilai kuat tekan, ketahan aus dan ketahanan kejut yang tinggi. Untuk hal tersebut, melalui penelitian ini dilakukan upaya untuk mendapatkan variasi dan

\footnotetext{
${ }^{1}$ Staf Pengajar Jurusan Teknik Sipil Politeknik Negeri Padang
} 
jenis campuran bahan tambahan dalam pembuatan paving block agar mempunyai mutu, khususnya kuat tekan yang tinggi.

\subsection{Tujuan dan Manfaat Penelitian}

Sesuai dengan latar belakang di atas, maka tujuan dari penelitian ini adalah sebagai upaya untuk memperoleh paving block dengan mutu kuat tekan yang tinggi dengan melakukan penambahan berbagai jenis serat pada campuran paving block.

Penelitian ini diharapkan memberikan suatu konstribusi bagi bidang teknik sipil, khususnya, memperoleh material bangunan yang bermutu baik dengan pemanfaatan material tambahan untuk memperbaiki sifat karakteristik bahan bangunan, terkhusu dalam hal ini adalah upaya untuk membuat paving block yang mempunyai kuat tekan tinggi, dan harapan lain memanfaatkan potensi bahan lain serta menanggulangi krisis dampak lingkungan.

Berdasarkan hasil penelitian nantinya diharapkan dapat diaplikasikan dalam pembangunan, yaitu penggunaan paving block yang lebih luas dan mampu memikul beban yang lebih berat dibanyak tempat. Dan pada saatnya dapat mengoptimlakan penggunaan material lokal yang tersedia, sehingga dapat meningkatkan pendapatan daerah, melalui sektor usaha industri rakyat berbasis potensi lokal.

\subsection{Perumusan Masalah}

Perkembangan ilmu pengetahuan dan teknologi bidang material konstruksi dewasa ini sangat pesat. Berbagai riset telah dikembangkan agar diperoleh material konstruksi yang kuat dan efisien. Begitu juga perkembangan pengetahuan dan teknologi untuk beton juga terus berkembang. Paving block merupakan produk dari beton yang merupakan material hasil campuran dari agregat kasar (kerikil), agregat halus (pasir), semen dan air.

Salah satu permasalahan penggunaan paving block adalah terjadinya pecah atau retak yang disebabkan oleh tegangan tarik dan desak yang terjadi, akibat beban lalu lintas melebihi kemampuannya. Dengan menambahkan serat pada campuran paving block, diharapkan akan berpengaruh terhadap sifat-sifat mekanik campuran tersebut. Prinsipnya dengan penambahan serat tersebut adalah untuk menulangi paving block, sehingga terbentuk ikatan yang lebih baik dari komponen penyusun paving block. Dengan demikian akan mencegah terjadinya retakan dan pecah pada paving block.

Jenis serat yang akan digunakan sebagai bahan tambahan campuran paving block terdiri atas serat ijuk, serat tali plastik, dan serat kawat bendrat. Secara garis besar perumusan masalah yang akan diselesaikan dalam penelitian ini adalah :

a. Berapa variasi panjang masing-masing serat yang dapat memberikan pengaruh terhadap kuat tekan paving block.

b. Berapa besar persentase masing-masing jenis serat yang bisa memberikan pengaruh kuat tekan yang tinggi pada paving block.

c. Jenis serat yang mana bisa memberikan nilai kuat tekan yang lebih tinggi.

Untuk menjawab permasalahan tersebut di atas, sebenarnya sudah banyak penelitian pendahulu yang melakukannya untuk memperbaiki kinerja mutu beton maupun paving block, maka pada penelitian ini selanjutnya kita ingin mengupayakan peningkatan kuat tekan paving block dengan alternatif penggunaan bahan tambahan beberapa jenis serat pada campuran paving block. 


\section{TINJAUAN PUSTAKA}

\subsection{Paving Block}

\section{a. Pengertian}

Paving block atau bata beton untuk lantai adalah suatu komponen bahan bangunan yang dibuat dari campuran semen hidrolis atau sejenisnya, agregat dan air dengan atau tanpa bahan tambahan lainnya yang tidak mengurangi mutu paving block tersebut. Paving block dapat berwarna seperti warna aslinya atau diberi zat pewarna pada komposisinya dan digunakan untuk lantai baik di dalam maupun di luar bangunan.

\section{b. Penggunaan di Indonesia}

Paving block mulai dikenal dan dipakai di Indonesia terhitung sejak tahun 1977/1978, dimulai dengan pemasangan trotoir di jalan Thamrin dan untuk terminal bus Pulogadung, keduanya di Jakarta. Saat ini paving block sudah tersebar pemakaiannya hampir di seluruh kota besar di Indonesia, baik digunakan sebagai tempat parkir plaza, hotel, tempat rekreasi, tempat bersejareah, untuk terminal maupun untuk jalan setapak dan perkerasan jalan lingkungan pada komplekskompleks perumahan.

\section{c. Bahan-bahan}

Bahan-bahan yang digunakan untuk paving block sama dengan concrete hollow block. Paving block terbuat dari bahan beton seperti agregat (batu pecah, pasir) bahan pengikat hidrolis (semen) dan air. Seperti pada pembuatan beton lainnya, persyaratan yang diperlukan untuk agregat, semen dan air yang digunakan harus memenuhi persyaratan seperti tercantum pada spesifikasi bahanbahan beton.

\section{d. Proses pembuatan}

Paving block dapat diproduksi secara mekanis, semi mekanis, atau dengan cetak tangan. Pada umumnya paving block yang diproduksi dengan peralatan mekanis memiliki mutu yang lebih tinggi daripada dengan cara lainnya. Bahan-bahan dicampur dalam perbandingan tertentu sesuai dengan peruntukan dan mutu yang direncanakan, kemudian dicetak dan dipadatkan dengan mesin getar, lalu disimpan pada tempat yang terlindung dari panas matahari langsung serta dari hembusan angin yang berlebihan. Paving block yang digunakan untuk jalan setapak, pertamanan dan lain-lain yang tidak menerima beban berat dapat menggunakan mutu kelas III, dengan perbandingan campuran 1 bagian berat semen dengan 5 bagian berat pasir, dengan cara konvensional (penekanan $\pm 20 \mathrm{~kg} / \mathrm{cm} 2$ ) . Untuk menjaga agar lebih tahan terhadap keausan dapat diberi lapisan kepala setebal $1 \mathrm{~cm}$ dengan perbandingan campuran 1 bagian berat semen dengan 3 bagian berat pasir dan faktor air semen yang digunakan berkisar antara $0,3-0,4$.

Untuk membuat paving block berkualitas tinggi, yang akan digunakan terus menerus khususnya di tempat dengan beban berat (misalnya tempat parkir), perbandingan adukan sebaiknya sebagai berikut :

1 bagian semen : 2 bagian pasir : 3 bagian kerikil + air secukupnya.

Untuk membuat paving block bermutu rendah, dapat digunakan lebih sedikit semen dan lebih banyak pasir sungai yang bersih pada adukan beton, yaitu :

1 bagian semen : 2 bagian pasir : 4 bagian kerikil + air secukupnya

1 bagian semen : 4 bagian pasir + air secukupnya

Paving block bermutu rendah ini dapat digunakan di dalam rumah, di halaman depan dan belakang rumah, dimana tidak ada beban berat yang menekan lantai.

VOLUME 10 NO. 1, FEBRUARI 2014 | 3 


\section{e. Berbagai pemakaian atau aplikasi paving block}

1) Paving block sebagai perkerasan jalan (sifat structural interblock). Pada mulanya paving block diperkirakan hanya berfungsi untuk memperindah lapisan permukaan perkerasan (pavement) dan tidak berfungsi sebagai struktur. Namun setelah dilakukan percobaan oleh J. Kanpton (Cement and Concrete Association 1976 di Inggris), terbukti bahwa lapisan perkerasan paving block mampu menyebarkan tegangan vertikal dengan baik, sehingga paving block berikut pasir ekstra beton sebagai "sand bending"dapat dianggap sebagai lapis permukaan pengganti lapis aspal (hotmix) dengan tebal tertentu.

2) Pedestrian (untuk pejalan kaki)

-Daerah pedestrian

-Pertamanan / landscaping

3) Industri

-Factory loading toys

-Lorry freight terminals

-Airport-aircraft parking areas

-Docks

\section{f. Persyaratan Mutu}

Persyaratan mutu paving block menurut SNI-03-0691-1996 sebagi berikut :

1) Sifat Tampak. Bata beton untuk lantai harus mempunyai bentuk sudut yang sempurna, tidak terdapat retak-retak dan cacat, bagian sududt dan rusuknya tidak mudah direpihkan dengan jari tangan.

2) Bentuk dan ukuran. Berbagai bentuk dan ukuran bata beton untuk lantai, terdapat di pasaran tergantung dari produsennya. Biasanya setiap produsen memberikan penjelasan tertulis dalam leaflet mengenai bentuk, ukuran dan daya dukung serta konstruksi pemasangannya untuk lantai.Penyimpangan tebal bata beton untuk lantai yang diperkenankan adalah $\pm 3 \mathrm{~mm}$.

3) Sifat Fisis. Bata beton untuk lantai harus mempunyai kekuatan fisis seperti tercantum pada tabel berikut :

Tabel 1: Kekuatan Fisis Paving Block

\begin{tabular}{|l|l|l|l|l|l|}
\hline \multirow{2}{*}{ Mutu } & Kuat Tekan (Mpa) & \multicolumn{2}{|l|}{ Ketahanan Aus (mm/menit) } & \multirow{2}{*}{ Penyerapan air, rata-rata (\%) } \\
\cline { 2 - 5 } & Rata-rata & Minimum & Rata-rata & Maksimum & \\
\hline I & 40 & 34 & 0,090 & 0,103 & 3 \\
\hline II & 30 & 22,5 & 0,130 & 0,149 & 5 \\
\hline III & 20 & 17 & 0,160 & 0,184 & 7 \\
\hline
\end{tabular}

\section{g. Keuntungan paving block}

1) Mudah dalam pemasangan dan pemeliharaan yang bersifat insidentil.

2) Dapat diproduksi baik secara mekanis, semi mekanis, maupun di cetak tangan.

3) Tidak mudah rusak oleh kendaraan.

4) Memperindah lapisan permukaan.

5) Anti slip.

6) Ukuran lebih terjamin.

7) Konsep pembangunan berwawasan lingkungan.

8) Tidak mudah rusak oleh perubahan cuaca (tahan terhadap cuaca) dan lain-lain.

9) Daya serap terhadap air hujan cukup baik, sehingga dapat mengurangi genangan air di halaman, karena pemasangan antara satu dengan yang lain tanpa menggunakan perekat/adukan semen, 


\subsection{Serat}

Berdasarkan dari beberapa hasil penelitian menunjukkan bahwa penambahan serat ke dalam beton akan meningkatkan kuat tarik beton, kuat lentur beton, kuat tekan dan daktalitas beton. Pertambahan kuat tarik akan memperbaiki kinerja komposit beton serat dengan kualitas yang lebih bagus dibandingkan dengan beton konvensional.

Keuntungan penambahan serat pada beton secara umum adalah berarti peningkatan ketahanan struktur bangunan (http://sipil2006.wordpress.com/) dan dapat dijelaskan sebagai berikut :

1) Serat terdistribusi secara acak di dalam beton pada jarak yang relatif sangat dekat satu dengan lainnya, sehingga akan memberikan tahanan terhadap tegangan berimbang ke segala arah dan memberi keuntungan material struktur yang disiapkan untuk menahan beban dari berbagai arah.

2) Perbaikan perilaku deformasi seperti ketahanan terhadap impak, daktalitas yang lebih besar, kuat lentur dan kapasitas torsi yang lebih baik.

3) Serat meningkatkan ketahanan beton terhadap formasi dan pembentukan retak

4) Peningkatan ketahanan pengelupasan (spalling) dan retak pada selimut beton.

Konsentrasi serat pada beton serat yang masih memungkinkan pengadukan serat dengan mudah adalah 2\% dari volume beton (Iskandar, dkk, 2004)

Ada bermacam-macam jenis serat yang dapat dipakai untuk pembuatan beton serat dan aplikasinya. Macam-macam serat tersebut adalah (Dwiyono, 2000) :

1) Serat asbestos. Dikenal serat asbestos putih (Crhysotile asbestos) yang mempunyai rumus kimia $3 \mathrm{MgO} .2 \mathrm{SiO} 2 . \mathrm{H} 2 \mathrm{O}$ dan Crodidolite asbestos yang mempunyai rumus kimia $\mathrm{Na} 2 \mathrm{O} . \mathrm{Fe} 2 \mathrm{O} 3.3 \mathrm{FeO} .8 \mathrm{SiO} 2 . \mathrm{H} 2 \mathrm{O}$. Serat ini mempunyai kuat tarik yang cukup tinggi sekitar 3500 Mpa. Namun banyak pendapat tentang bahaya serat ini terhadap kesehatan manusia, dianggap sebagai salah satu penyebab penyakit kanker. (karsiorganik).

2) Serat kaca (glass fiber). Serat ini mempunyai kuat tarik yang cukup tinggi, sehingga penambahan serat kaca pada beton akan meningkatkan kuat lentur beton. Tetapi permukaan serat kaca yang licin mengakibatkan daya lekat terhadap bahan ikatnya menjadi lemah dan serat ini kurang tahan terhadap sifat alkali semen sehingga dalam jangka waktu lama serat akan rusak.

3) Serat baja (steel fiber). Mempunyai kuat tarik dan modulus elastisitas yang cukup tinggi, tidak mengalami perubahan bentuk akibat pengaruh sifat alkali semen.

4) Serat karbon. Mempunyai kelebihan tahan terhadap lingkungan agresif, stabil pada suhu tinggi, tahan terhadap abrasi, relatif kaku dan lebih tahan lama.

5) Serat polypropylene. Dalam kehidupan sehari-hari dikenal sebagai tali rafia, mempunyai sifat tahan terhadap serangan kimia, permukaannya tidak basah sehingga mencegah terjadinya penggumpalan serat selama pengadukan, mempunyai titik leleh $1650 \mathrm{C}$ dan mampu digunakan pada suhu lebih dari 1000C untuk jangka waktu pendek.

6) Serat polyethylene. Dikenal sebagai tali tambang plastik, sifatnya hampir sama dengan serat polypropylen, hanya bentuknya berupa serat tunggal.

7) Serat alami. Ada bermacam-macam serat alami, antara lain : abaca, sisal, jute, ramie, ijuk, serat serabut kelapa dan lain-lain. Serat ijuk yaitu serabut berwarna hitam dan liat, yang terdapat pada bagian pangkal dan pelepah daun pohon aren. Pohon aren menghasilkan ijuk pada 4-5 tahun terakhir. Serat ijuk yang bagus diperoleh dari pohon yang sudah tua, tetapi sebelum tandan (bakal) buah muncul (sekitar umur 4 tahun), karena saat tandan (bakal) buah muncul ijuk menjadi kecil-kecil dan jelek. (Wiryawan, 2007). Ijuk yang dihasilkan pohon aren mempunyai sifat fisik diantaranya : berupa helaian benang (serat) berwarna hitam, berdiameter kurang dari , $5 \mathrm{~mm}$, bersifat kaku dan ulet (tidak mudah putus. Selama ini pemanfaatan ijuk belum terlalu banyak yaitu diantaranya sebagai bahan pembuat sapu dan tali tambang. Masih banyak serat ijuk yang belum dimanfaatkan sehingga terbuang percuma. Perkembangan teknologi 
memungkinkan perluasan pemanfaatan serat ijuk, diantaranya sebagai pengisi bahan bangunan. Ijuk bersifat lentur dan tidak mudah rapuh, sangat tahan terhadap genangan asam termasuk gengan air laut yang mengandung garam. Dengan karakteristik ijuk seperti ini maka diharapkan dapat memperbaiki sifat kurang baik beton. (http://arengabroom.blogspot.com/) . Komposisi kandungan unsur kimia pada serat ijuk adalah :

$\begin{array}{ll}\text { Selulosa } & 51,54 \% \\ \text { Hemiselulosa } & 15,88 \% \\ \text { Lignin } & 43,09 \% \\ \text { Air } & 8,9 \% \\ \text { Abu } & 2,54 \%\end{array}$

\subsection{Kuat Tekan}

Kuat tekan suatu material didefinisikan sebagai kemampuan material dalam menahan beban atau gaya mekanis sebagai kemampuan material dalam menahan beban atau gaya mekanis sampai terjadinya kegagalan (failure). Kuat tekan beton dapat diperoleh dengan menggunakan rumus :

$$
\tau=\mathrm{F} / \mathrm{A}
$$

Dimana : $\quad \tau=$ Kuat tekan $(\mathrm{N} / \mathrm{cm} 2)$

$\mathrm{F}=$ Beban maksimum $(\mathrm{N})$

$\mathrm{A}=$ Luas Bidang Permukaan (m2)

\section{METODOLOGI PENELITIAN}

Pengujian yang berhubungan dengan komponen material penyusun campuran paving block. Material yang digunakan dalam penelitian meliputi :

a). Agregat. Agregat standar digunakan agregat batu pecah dari stone crusher produksi Quarry PT. ATR yang berlokasi di jalan ByPass Padang

b). Semen. Semen yang digunakan adalah semen PCC produksi PT Semen Padang

c). Serat. Ada 3 jenis serat yang akan digunakan sebagai variasi bahan tambahan campuran, yaitu serat ijuk, serat plastik dan serat kawat bendrat.

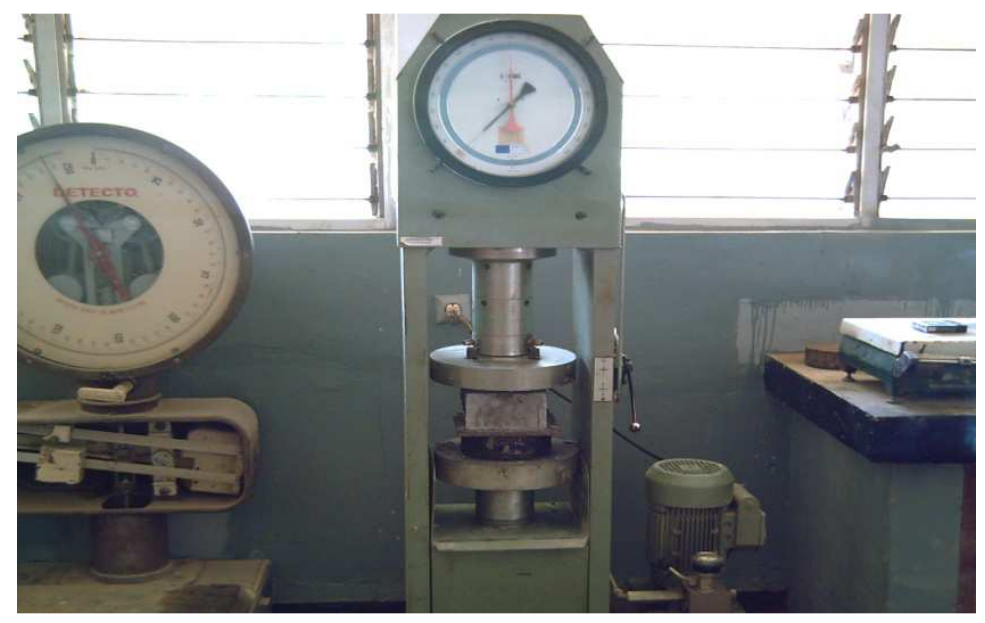

Gambar 1 : Alat Uji Tekan Beton

\section{I JURNAL REKAYASA SIPIL}


Peralatan yang akan digunakan adalah berupa alat-alat untuk uji material properties dan peralatan uji tekan beton dan alat cetak paving block mekanis. (Gambar .1) dan selanjutnya kegiatan penelitian ini akan dilakukan menurut diagram rencana kerja seperti terlihat pada Gambar 2.

\subsection{Prosedur Laboratorium}

1) Rancangan campuran. Rancangan campuran paving block adalah direncanakan untuk mutu kuat tekan beton K 300 dengan mengoptimalkan penggunaan serat sebagai bahan tambahan campuran.

2) Rancangan jumlah benda uji. Untuk mendapatkan gambaran optimalisasi pemakaian serat sebagai bahan tambahan dilakukan variasi campuran dengan rentang 0\% sampai 5\% dari volume beton, dan variasi panjang serat $1 \mathrm{~cm}, 2 \mathrm{~cm}$ dan $3 \mathrm{~cm}$ dengan masing-masing variasi sebanyak 5 benda uji, sehingga jumlah benda uji adalah :
a. Campuran standar tanpa serat
: 5 buah
b. Variasi tambahan serat ijuk
: 75 buah
c. Variasi tambahan serat tali plastic
: 75 buah
d. Variasi tambahan serat bendrat
: 75 buah
Jumlah benda uji $\quad: 230$ buah

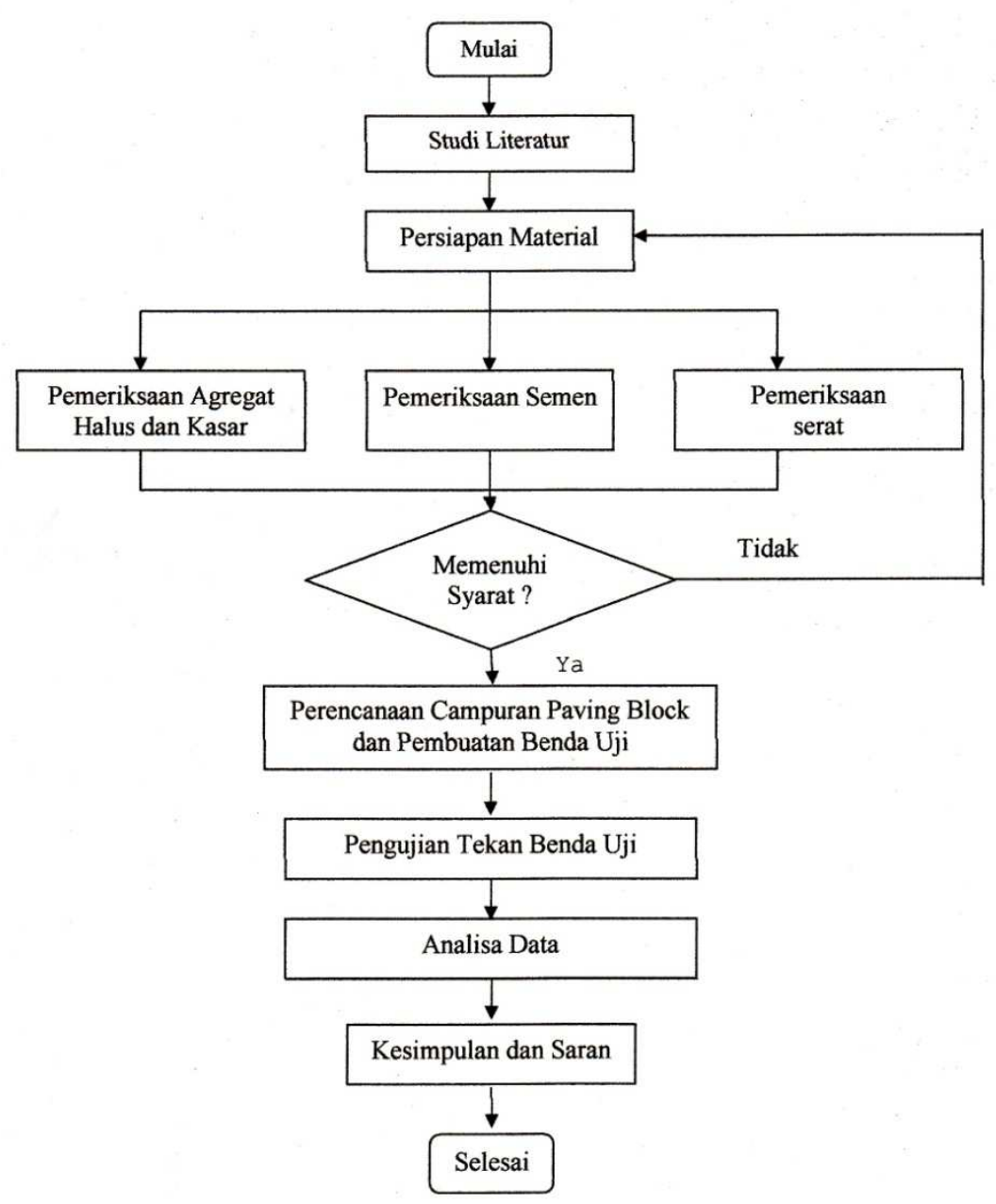

Gambar 2 : Diagram Rencana Kerja 


\subsection{Pembuatan benda uji dan kuat tekan}

Pembuatan benda uji dilakukan dengan sesuai komposisi variasi campuran yang direncanakan, dimana masing-masing variasi dibuat 5 benda uji. Proses pencampuran sesuai prosedur pencampuran beton diaduk sampai homogen merata dengan penambahan air sesuai kelecakan yang diinginkan (6\% sampai $12 \%$ dari total jumlah material (semen + pasir + kerikil).

Penuangan campuran beton basah dalam cetakan paving block type bata tebal 6-7 $\mathrm{cm}$ dilakukan bertahap dengan diselingi penusukan untuk membantu pemadatan. Selanjutnya pemadatan dibantu dengan alat penggetar, dan untuk mendapatkan kepadatan yang optimum sesuai persyaratan pembuatan paving block dilakukan penekanan dengan alat tekan sebesar $50 \mathrm{~kg} / \mathrm{cm} 2$. Pembukaan benda uji dilakukan setelah benda uji mengalami ikatan awal sekitar 24 jam, dan selanjutnya dilakukan perawatan benda uji dengan menempatkan pada tempat yang terlindung. Pengujian kuat tekan dilakukan seperti prosedur pengujian uji tekan beton, dimana kekuatan tekan diestimasi untuk umur beton 28 hari.

\section{PEMBAHASAN}

Dari pengujian kuat tekan yang dilakukan dengan alat Compression Testing Machine (CTM) didapatkan beban maksimum yaitu beban pada saat paving block hancur saat menerima beban maksimum (Pmak). Dari data beban tersebut diperoleh tegangan hancur (disebut juga sebagai kuat tekan maksimum). Hasil kuat tekan benda uji dapat selengkapnya dilihat pada lampiran. Berikut pada gambar 3 dapat dilihat perbandingan kuat tekan paving block yang dihasilkan dari penambahan serat ijuk dibandingan dengan kuat tekan paving block standar. Dan dari data tersebut dapat diinformasikan sebagai berikut :

1. Kuat tekan rata-rata paving block standar didapatkan $327,38 \mathrm{~kg} / \mathrm{cm} 2$

2. Pada penambahan serat ijuk $1 \mathrm{~cm}$ diperoleh hasil tertinggi kuat tekan rata-rata pada penambahan $1 \%$ serat terhadap campuran yaitu sebesar $276,9 \mathrm{~kg} / \mathrm{cm} 2$.

3. Pada penambahan serat ijuk $2 \mathrm{~cm}$ diperoleh hasil tertinggi kuat tekan rata-rata pada penambahan $5 \%$ serat terhadap campuran yaitu sebesar $274,95 \mathrm{~kg} / \mathrm{cm} 2$.

4. Pada penambahan serat ijuk $3 \mathrm{~cm}$ diperoleh hasil tertinggi kuat tekan rata-rata pada penambahan $2 \%$ serat terhadap campuran yaitu sebesar $323,98 \mathrm{~kg} / \mathrm{cm} 2$.

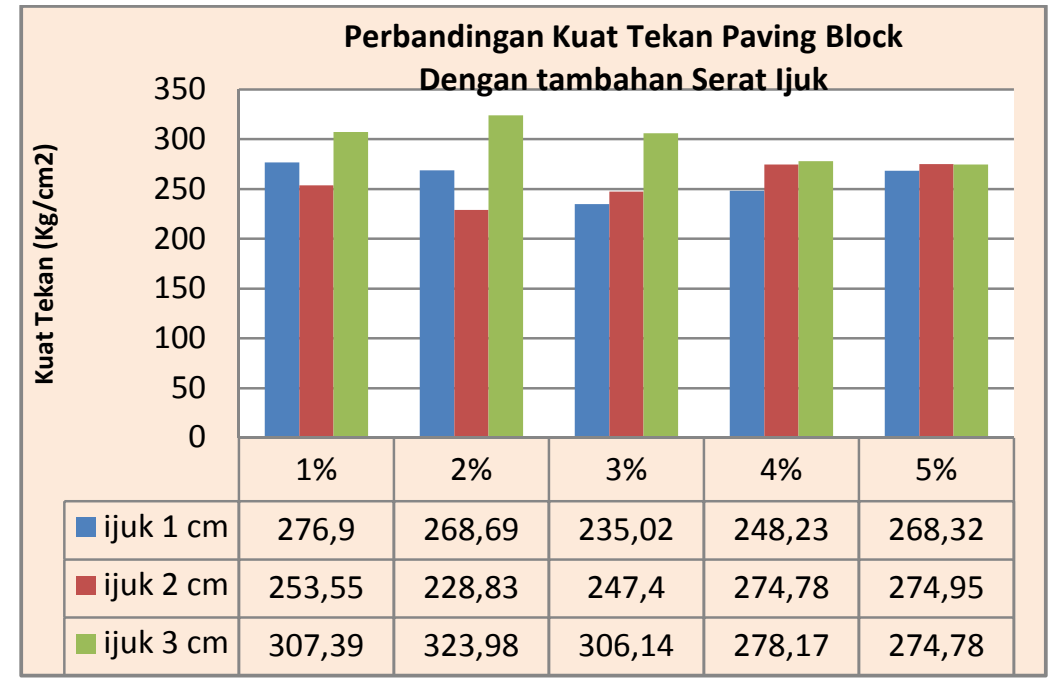

Gambar 3 Perbandingan Kuat Tekan Paving Block dengan Penambahan Serat ijuk 
Kuat Tekan paving block standar rata-rata $=327,38 \mathrm{~kg} / \mathrm{cm} 2$. Berikut pada gambar 4 dapat dilihat perbandingan kuat tekan paving block yang dihasilkan dari penambahan serat plastik dibandingan dengan kuat tekan paving block standar. Dan dari data tersebut dapat diinformasikan sebagai berikut :

1. Kuat tekan rata-rata paving block standar didapatkan $327,38 \mathrm{~kg} / \mathrm{cm} 2$

2. Pada penambahan serat plastik $1 \mathrm{~cm}$ diperoleh hasil tertinggi kuat tekan rata-rata pada penambahan $2 \%$ serat terhadap campuran yaitu sebesar $323,59 \mathrm{~kg} / \mathrm{cm} 2$.

3. Pada penambahan serat plastik $2 \mathrm{~cm}$ diperoleh hasil tertinggi kuat tekan rata-rata pada penambahan $3 \%$ serat terhadap campuran yaitu sebesar $325,10 \mathrm{~kg} / \mathrm{cm} 2$.

4. Pada penambahan serat plastik $3 \mathrm{~cm}$ diperoleh hasil tertinggi kuat tekan rata-rata pada penambahan $2 \%$ serat terhadap campuran yaitu sebesar $279,99 \mathrm{~kg} / \mathrm{cm} 2$.

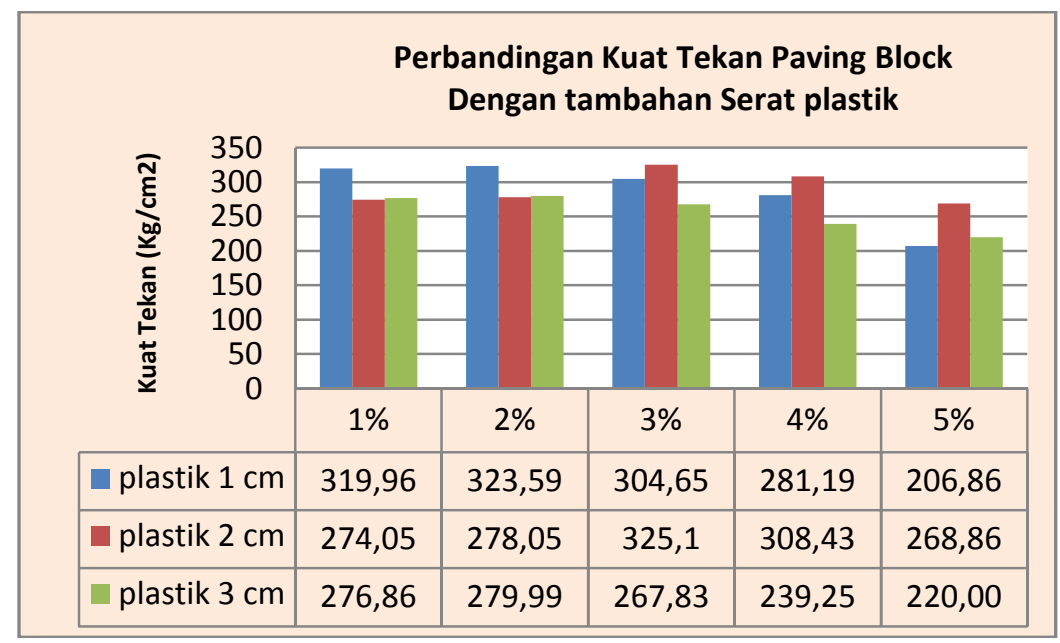

Gambar 4 Perbandingan Kuat Tekan Paving Block dengan Penambahan Serat plastik

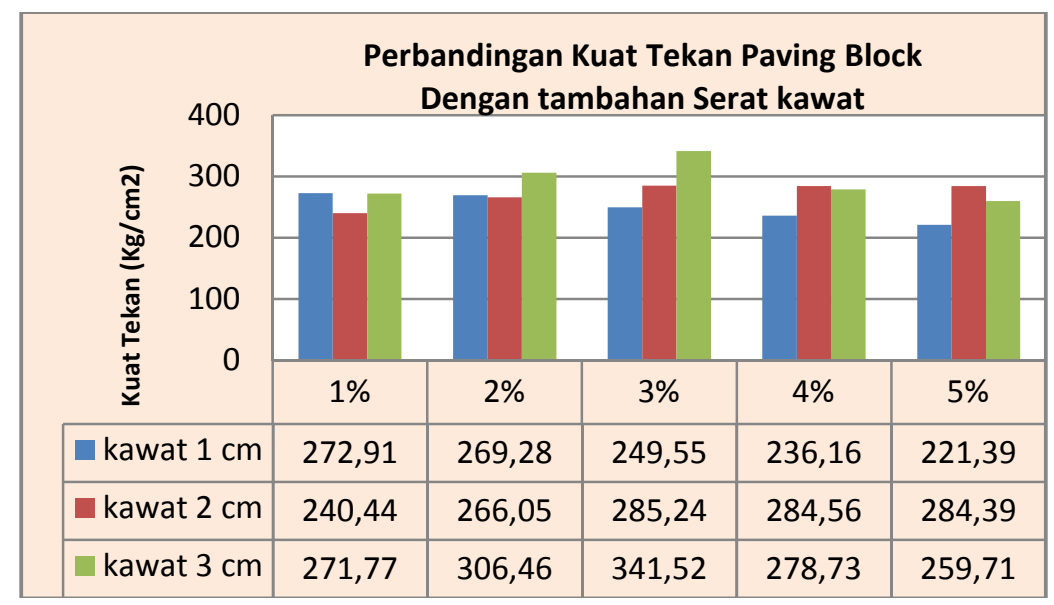

Gambar 5 Perbandingan Kuat Tekan Paving Block dengan Penambahan Serat kawat

Berikut pada gambar 5 dapat dilihat perbandingan kuat tekan paving block yang dihasilkan dari penambahan serat kawat dibandingan dengan kuat tekan paving block standar. Dan dari data tersebut dapat diinformasikan sebagai berikut :

a. Kuat tekan rata-rata paving block standar didapatkan $327,38 \mathrm{~kg} / \mathrm{cm} 2$ 
b. Pada penambahan serat kawat $1 \mathrm{~cm}$ diperoleh hasil tertinggi kuat tekan rata-rata pada penambahan $1 \%$ serat terhadap campuran yaitu sebesar $271,91 \mathrm{~kg} / \mathrm{cm} 2$.

c. Pada penambahan serat kawat $2 \mathrm{~cm}$ diperoleh hasil tertinggi kuat tekan rata-rata pada penambahan $3 \%$ serat terhadap campuran yaitu sebesar $285,24 \mathrm{~kg} / \mathrm{cm} 2$.

d. Pada penambahan serat kawat $3 \mathrm{~cm}$ diperoleh hasil tertinggi kuat tekan rata-rata pada penambahan $3 \%$ serat terhadap campuran yaitu sebesar $341,52 \mathrm{~kg} / \mathrm{cm} 2$.

\section{KESIMPULAN}

Berdasarkan perbandingan kuat tekan yang diperoleh dari masing-masing variasi penambahan serat pada paving block terhadap kuat tekan standar, maka beberapa hal dapat disimpulkan sebagai berikut :

1. Secara prinsip ternyata penambahan serat (ijuk, plastik, kawat) sampai $5 \%$ terhadap campuran paving block tidak memberikan nilai yang significant terhadap penambahan kuat tekan paving block, malah sebagian campuran memberikan kecenderungan penurunan kuat tekan dibandingkan dengan kuat tekan paving block standar sebagai pembanding.

2. Untuk penambahan serat ijuk hanya penambahan serat panjang $3 \mathrm{~cm}$ dengan kadar 1 sampai $3 \%$ saja yang memberikan kekuatan tekan rata-rata di atas K 300. Kekuatan tekan rata-rata maksimum hanya diperoleh sebesar $323,98 \mathrm{~kg} / \mathrm{cm} 2$ pada penambahan serat ijuk panjang $3 \mathrm{~cm}$ dengan persentase penambahan serat $2 \%$.

3. Untuk penambahan serat plastik kekuatan $\mathrm{K} 300$ tercapai hanya pada penambahan serat panjang $1 \mathrm{~cm}$ pada kadar 1 sampai $3 \%$ dan panjang $2 \mathrm{~cm}$ pada kadar $3 \%$. Kekuatan tekan rata-rata maksimum hanya diperoleh sebesar $325,10 \mathrm{~kg} / \mathrm{cm} 2$ pada penambahan serat ijuk panjang $2 \mathrm{~cm}$ dengan persentase penambahan serat $3 \%$.

4. Sedangkan untuk penambahan serat kawat kekuatan K 300 tercapai pada penambahan serat kawat panjang $3 \mathrm{~cm}$ pada kadar 2 dan $3 \%$ saja. Kekuatan tekan rata-rata maksimum hanya diperoleh sebesar $341,52 \mathrm{~kg} / \mathrm{cm} 2$ pada penambahan serat ijuk panjang $3 \mathrm{~cm}$ dengan persentase penambahan serat $3 \%$.

Mempertimbangkan hasil yang diperoleh dari kesimpulan, maka penulis melihat kemungkinan lain untuk menindak lanjuti penelitian ini terhadap model, variasi dan perlakuan serat pada campuran paving block, sehingga fungsi serat dapat meningkatkan kuat tekan paving block sebagaimana yang diharapkan. Untuk melihat fungsi serat lebih optimal dapat dipertimbangkan juga untuk melakukan uji tarik paving block.

\section{DAFTAR KEPUSTAKAAN}

Amir, A.H., dkk, 2002, Pengembangan Pemanfaatan limbah Pertambangan Dan Industri Untuk Komponen Bangunan (Laporan Proyek), Pusat Penelitian dan Pengembangan Permukiman, Bandung

Amri, Sjafei, 2005, Teknologi Beton A - Z, Penerbit Universitas Indonesia, Jakarta.

Hidayat, Y.S., dan Andriati Amir Husin, 1990, Penelitian Pemanfaatan Semen Abu Terbang untuk Bahan

Komponen Bangunan (laporan Proyek), Puslitbang Pemukiman, Badan Penelitian dan Pengembangan,

Departemen Pekerjaan Umum, Bandung.

http://sipil2006.wordpress.com/

http://arengabroom.blogspot.com/

http://www.iptekda.lipi/root/buletin_detail_cetak.asp?berita_id

http://www.ilo.org/publns;

http://www.lemigas.esdm.go.id/node/506

http://www.padangekspres.co.id/mod.php.mod

http://www.kimpraswil.go.id/balitbang/puskim/homepage

http://pib-banten.go.id/arsip/artikel 
SNI-03-0691-1996, Persyaratan mutu bata beton (paving block)

SNI 03-1969 -1990, Metode pengujian Berat jenis dan Penyerapan air agregat kasar SNI 03-1970 -1990, Metode Pengujian Berat jenis dan Penyerapan air agregat halus 